\title{
FRENCH LITERATURE: FROM REALISM TO MAGICAL REALISM
}

\author{
Ali Shahab1, Faruk², Muh. Arif Rokhman² \\ Universitas Gadjah Mada, Indonesia. \\ 1ali.shahab@ugm.ac.id, 2farukkhan@ugm.ac.id, 3arokhman@ugm.ac.id \\ Article accepted : August - $19-2020$ \\ Revised article: November - 05 - 2020 \\ Approved article: November - 15 - 2020
}

\begin{abstract}
The purpose of the article is to explore the evolution of French literature between the late $19^{\text {th }}$ century and early $21^{\text {st }}$ century. Although French literature has long been dominated by rationalistic ways of thinking, based on the thoughts of René Descartes and John Locke, authors have used different means to express their perceptions of society. The novel Madame Bovary (1856), including its depiction of conjugal relationships, can be considered to have pioneered realism in French literature. During the Second World War, existentialism and absurdism appeared as new ways of examining not only the relationship among humans, but also between humans and God. In the late $20^{\text {th }}$ century, magical realism emerged as a new literary stream that explicitly recognized the irrationality of human thinking. This article finds that the rationality of realism was necessary for magical realism to be accepted; in this rationality, although works of magical realism were irrational, they had to be recognized as fine examples of French literature that embodied such revolutionary ideas as liberté (liberty), égalité (equality), and fraternité (fraternity). To study this phenomenon, we examine the history of french literature by applying archeological method in order to understand the world views of the authors and how they change over time.
\end{abstract}

Keywords: realism, existentialism, magical realism, French, literature

\begin{abstract}
Abstrak
Penelitian ini mencoba mengeksplorasi evolusi sastra Prancis antara akhir abad XIX dan awal abad ke-21. Pada abad XIX sastra Prancis didominasi oleh cara berpikir rasionalistik berdasarkan pemikiran René Descartes dan John Locke, dengan contoh Novel Madame Bovary (1856) yang dianggap sebagai pelopor realisme dalam sastra Prancis. Selama Perang Dunia Kedua, eksistensialisme dan absurdisme muncul sebagai cara baru untuk mempertanyakan hubungan antar manusia, dan antara manusia dengan Tuhan. Pada awal abad ke-21, realisme magis muncul sebagai aliran sastra baru yang secara eksplisit mengakui irasionalitas pemikiran manusia. Rasionalitas realisme diperlukan agar realisme magis dapat diterima dalam rasionalitas ini, meskipun karya realisme magis tidak rasional, harus diakui sebagai contoh dari sastra Prancis yang mewujudkan ide-ide revolusioner seperti liberté (kebebasan), égalité (kesetaraan), dan fraternité (persaudaraan). Hal ini membuktikan bahwa rasionalitas pada dirinya bersifat otoriter dan memerlukan liyan, yaitu irasionalitas. Penelitian dilakukan dengan cara meneliti ke belakang secara arkeologis kesejarahan sastra Perancis, untuk melihat perubahan pandangan dunia yang muncul pada setiap zamannya.
\end{abstract}

Kata kunci: realisme, eksistensialisme, realisme magis, sastra Prancis

\section{INTRODUCTION}

In the beginning, French literature was instilled with a spirit of rationalism, as evi- dent in the literary works of the $19^{\text {th }}$ century. For instance, in his debut novel Madame Bovary (1856), Gustave Flaubert (1821-1880) relied heavily on literary realism, seeking to present 
reality objectively, without exaggeration or understatement (A. K Hadimaja, 1972: 71). At the same time, the novel's plot was developed through a causal chain, with every event and incident instigated by a previous one. In this, Flaubert drew on the philosophy of René Descartes (1596-1650) and John Locke (1632-1704); the former, famous for his proposition cogito ergo sum (je pense donc je suis, or I think, therefore I am), accepted only that which was free of doubt (Hatfield, 1993, 2008, 2013), while the latter rejected the notion that intuition creates being (Uzgalis, 1988, 2017). Such paradigms influenced French literature significantly, and Madame Bovary (1856) remains a prime example of a work influenced by Cartesian notions of truth (Watt, 1982: 15).

However, over time realism, as well as the Cartesian rationality that underpinned it, began to wane. A widespread sense of disappointment, which became particularly prominent after the horrors of World War I and World War II, resulted in French philosophers challenging the Cartesian philosophy. Driven primarily by Jean-Paul Sartre (19051980) and Albert Camus (1913-1960), French thinkers promoted new philosophies that revolved around the notion of free will. Sartre, for instance, promoted an existentialist philosophy through works such as L'Etre et le néant (Being and Nothingness) (1943) and L'Existensialisme est un humanism (Existentialism is a humanism) (1946), while
Camus conveyed an absurdist worldview through such works as L'Etranger (The Stranger) (1941) and Le Mythe de Sisyphe (The Myth of Sisyphus) (1942) (Udasmoro, 2012; Udasmoro \& Shahab, 2013).

In the 1980s, decades after the emergence of these philosophies (as well as related ones such as surrealism [1920s-1950s] and nouveau roman [1950s]), French literature was transformed by a new approach to writing: magical realism. One pioneer of this new style was Tahar Ben Jelloun (he was born in Morocco in 1944. He remains active even today, having published his most recent novel L'Insomnie (Insomia, 2019) on January 10, 2019) whose works-including L'Enfant de Sable (The Sand Child) (1984) and the Prix Goncourt-winning in 1987 La nuit sacrée (The Sacred Night) (1985) - differed significantly from mainstream works of French literature in that they abandoned causality in favor of an absurdist and irrational narration. This shows that French philosophy has not evolved consistently, transforming from a rational and mathematical framework into an increasingly irrational one. It is thus necessary, first, to trace the evolution of French literature from rationalism to absurdity and magical realism through French literature, and, second, to understand how authors understood and represented this evolution. In order to trace their evolution and expose the paradigms contained within, these three approaches to literature (particularly their positioning of rationalism) will be studied comparatively. 
To study this phenomenon, we look back the historical of french literature to see its pasts, using archeological method to see the world views of the authors, then we compare those world views to see their changes. This article consists of four sections. First, it describes the philosophy of rationalism, the foundation of realism. Second, it explores realism within the dynamic context of France and England, with a particular focus on its evolution into magical realism. Finally, it offers empiric evidence of how realism has transformed in French literature.

\section{Descartian and Lockean Rationalism in}

\section{European Thought}

In the 1600 s, positivism was emerging in three aspects of European society: theology i.e. all that related to divinity; metaphysics i.e. all that related to the origin and purposes of life; and humanity i.e. all that related to the tangible and rational elements of human life rather than the spiritual. In this third field, which ultimately became dominant, faith in God or another higher power was inconsequential (A. K Hadimaja, 1972: 92). French literary realism developed upon a foundation of Descartian rationality, particularly his famed proposition cogito ergo sum. At the same time, it drew influence from the thought of the English free-thinker John Locke, whose philosophy was inspired by (but also departed from) that of René Descartes and his Le Discours de la Méthode
(Discourse on the Method, 1637).

Ultimately, both French and English positivism were driven by rationality and opposed irrationality. However, these views were not entirely shared. French positivism was more conceptual (thought-based), while English positivism was more empiric (experience-based). Descartes, one of the earliest proponents of positivism in France, rejected the use of experiments. Meanwhile, Locke rejected human intuition and rationality, including the deductive reasoning taught by Descartes. Instead, he offered an experiment-based empirical approach that promoted inductive reasoning.

Because the positivism that developed in France differed from that which developed in England, these philosophies shaped the behaviors of the French and English peoples differently. Locke's empirical philosophy spurred the English to develop a strong navy with advanced arms, to explore new lands, and to practice widespread imperialism; ultimately, although both countries practiced colonialism, England controlled more lands than France. Similarly, Lockean empiricism-as modified by the Marxist philosophy that developed in the mid-19th century-was a cornerstone of the English industrial revolution. This philosophy allowed for the development of new and more effective modes of production, which brought with them, in turn, significant socio-cultural changes.

In France, meanwhile, more emphasis was given to conceptual thought and rational logic, which provided fertile ground for the advance 
of realism in the French arts. Foucault (1969), employing the archeology of knowledge, found that three epistemes $3 / 4$ the term 'episteme' (épistémè) to refer to a strategic dispositive through which knowledge is filtered to condition the "possibility of all knowledge, whether expressed in a theory or silently invested in a practice". It makes it possible to ascertain whether something is scientific, whether something can be qualified, and therefore whether something can be deemed true or false. It is an epistemological norm that shapes the production of knowledge in a particular epoch. Foucault also uses the term 'discourse' (énoncé discoursive) to refer to a constitutive element that gives shape and material form to particular ideas. Although he borrows from linguistics, his analysis is not linguistic (Foucault, 1969: 250) 3/4had shaped French culture and history between the fifteenth and midtwentieth centuries: the renaissance (fifteenth to mid-seventeenth centuries), classic (mid-seventeenth to mid-nineteenth centuries), and modern (mid-nineteenth to late twentieth centuries).

In the twentieth century, the French episteme transformed increasingly rapidly as Europeans sought to better understand the rapidly changing times. As such, realism gave way to existentialism, and this gave way to magical realism. Nonetheless, these approaches to literature-particularly realism-faced significant obstacles and ideologi- cal/political resistance. Particularly prominent was criticism from orthodox Christians, whose concepts and practices remained dominated by religious doctrines and dogms (Becker, 1982: 8).

\section{The Dynamics of Realism}

Since the seventeenth century, numerous authors have shaped European minds and approaches to knowledge. Writers such as Montesquieu (1689-1755) and Jean-Jacques Rousseau (1712-1778), bucked the moralistic discourses of the Church and thereby shaped public discourse throughout the Enlightenment (Becker, 1982: 19). In his L'esprit de la loi (The Spirit of Laws, 1748). Montesquieu challenged the political structure of France. Desiring to prevent the abuse of power common, he sought to replace the existing trias politica (monarchy, aristocracy, and commons) with a new one (executive, legislative, and judicative). His concept, with some revisions, is still applied in countries around the world-including in Indonesia.

Around this time, Denis Diderot (17131784) prepared Europe's first encyclopedia. Simply titled Encyclopédie, it sought to free humanity from illusions and pointless power struggles by promoting a scientific approach. Philosophy, once dominated by the Catholic Church, was no longer speculative, but scientific. Similarly, the social sciences-such as sociology and psychology-became increasingly 
rational. A new form of literature, known as realism, developed rapidly in the fertile soil of this paradigm shift (Becker, 1982: 8)

Building on this realism, social scientists such as Henri de Saint-Simon (1760-1825) and Auguste Comte (1798-1857) developed a foundation for positivism (Bryant, 1985: 43). One of the most prominent proponents of positivism was Hypolyte Taine (18231893), a writer and chemist whose works significantly shaped French realism (as recognized by Emile Zola, who identified himself as having been influenced significantly by Taine). By the 1860s, works of literature had begun to incorporate scientific knowledge, as featured prominently in the oeuvre of Jules Verne (1828-1905), including Voyage au centre de la terre Uourney to the Centre of the Earth, 1863; expanded 1867), De la terre à la lune (From the Earth to the Moon, 1865), Autour de la lune (Around the Moon, 1870), Vingt mille lieues sous les mers (Twenty Thousand Leagues Under the Sea, 1870), and Le Tour du monde en quatre-vingts jours (Around the World in Eighty Days, 1873).

Positivism was not limited to France. English authors asuch as John Stuart Mill (1806-1873), Jeremy Bentham (1748-1832), and Herbert Spencer (1820-1903) were significantly influenced by the writings of $\mathrm{Au}$ guste Comte, who himself drew heavily from René Descartes (1596-1650). However, realism had comparatively little effect on English literature. Authors such as Daniel Defoe
(1660-1731), Henry Fielding (1707-1754), and George Crabbe (1754-1832), though employing realism in their works, used a style that appeared forced (Becker, 1982: 135). For instance, D. H Lawrence (1885-1930) borrowed from realism in his Sons and Lovers (1913)considered one of the most important English novels of the twentieth century-but was ultimately only able to approximate it. Elements of romanticism, a movement with deep roots in English literature, remained evident; such works have thus been identified as "beyond realism" (Becker, 1982: 141).

One literary critic, Carmelo Bonet (18861977), described this period as one in which intellectualism spread quickly and widely. Even as no individuals identified themselves as its motors, positivism reached and spread through the grassroots. Realism promoted a deductive mindset, one that became embedded in social life (Becker, 1982: 25).

\section{From Realism to Absurdism to Magical Real-} ism

One important figure in early French realism was Henry Marie Baile, better known as Stendhal (1783-1842). In his works, including Le rouge et le noir (The Red and The Black) (1830) and La chartreuse de parme (The Charterhouse of Parma) (1839), Stendhal employed a deductive approach, emphasizing humanity's control of the world and the disenfranchisement of those who lacked such control. In his 
works, Stendhal depicted individuals who were guided by an essentialist mindset, driven by little more than sexual desire (Becker, 1982: 143-144). In this context, sexual desire was becoming an important part in the creation of humanity. French philosophers started to think that the psychological aspects of human being was very crucial in controlling the world. Sexual desire wan an integral part of human realism.

However, the term realism itself was first popularized in France by Gustave Courbert (1819-1877), an artist and art critic. He initially used the term to refer to those works that had been rejected by the Salons and displayed on the streets of Paris. The realism was then could be considered as part of the artist's struggle to show their reality of human that was previously denied because of the presence of the high-class arts. In 1855, Fernand Desnoyers (1826-1869) published an article that he deemed realism. The following year, Champfleury published a volume titled simply Realisme (Realism, 1856), while Louis Edmond Duranty (1833-1880) published a series of reviews on the topic over the course of several months. For realists such as Duranty, the main goal of literature is to highlight the most prominent elements of human life. All births, marriages, and deaths, be they experienced by the rich or the poor, are worthy of documentation. Such an approach was also prominently used by Flaubert (Kelly, 1991: 197). The realism was representing different human corners. Realism was not only representing certain groups of people, especially the dominant culture, but also the marginal groups in the society.

From France, realism spread rapidly throughout Europe. In England, where the philosophy of John Locke continued to hold sway, Charles Darwin (1809-1882) stirred controversy with the publication of his Origin of Species (1859). His thinking was criticized by European scholars but it showed a new way how the Western authority imagined the word (Tang, 2017). In Italy, the fall of the Papal States led to the cessation of theological education at universities. As a result of such revolutionary ideas, the sacrality and the power of the Church over the common people was eroded. Philosophy and science became increasingly free of the influence of religion (Becker, 1982: 20). However, the rise of rationality created also other marginalizations. The churches had lost power and it was starting the clash between church and science, especially in Europe and in America (Masch, 2019; Tang, 2017).

Another writer who challenged the orthodoxy of mid-eighteenth-century Europe, particularly its essentialist ideas of the being and the subject, was Pierre-Joseph Proudhon (18091865). In his Philosophie du Progrès (1853), which he wrote while in prison, he argued against idealism and absolutism. As he wrote:

"That which dominates all my studies, its principle and end, its summit and base, in a word, its reason; that which gives the key to all my controversies, all my disquisi- 
tions, all my lapses; that which constitutes, finally, my originality as a thinker, if I may claim such, is that I affirm, resolutely and irrevocably, in all and everywhere, Progress, and that I deny, no less resolutely, the Absolute." (Becker, 1982: 22).

Before Madame Bovary (1856), several works with realist leanings had been published by writers such as Honoré de Balzac (1799-1850)_and his student Emile Zola (1840-1902) (Rehandini, 2015). However, both writers had their own shortcomings. Balzac, despite having realist tendencies, presented heritage and environment as the prime shapers of human character (Udasmoro, 2015). His own voice was patently evident in his works, and thus it may be concluded that he was unable to capture the Darwinian struggle to survive. In his romanfleuve, a multi-volume collection of interlinked novels titled collectively La comédie humaine (The Human Comedy, 1829-1848), he thus depicted several types of human beings. In his expansive oeuvre, he depicted such varied topics as Parisian life, agrarian life, military life, mercantile life, etc.

Meanwhile, although Zola professed himself to be a student of Balzac, he also drew from the works of Taine. Known as a naturalist, Zola believed that the human mind is shaped by physiological factors (Lagarde \& Michard, 1966: 400). In other words, humans are influenced by their physical experiences.

"My characters are not the human be- ings with the pure thoughts of those abstract beings from the eighteenth century. They are the subjects of present-day knowledge, organic peoples living, and interacting with their environment. All of their feelings will interact with their soulds. In all of their activities, their souls will be preceded by their sense of sight, smell, hearing, taste, and touch. The concept of the soul as a separate entity is mistaken. It is a psychological mechanism, not a life." (Lagarde \& Michard, 1966: 483).

Realists sought to distinguish themselves from romantics, who explored life through a subjective perspective. This is best exemplified by Madame Bovary (Flaubert, 1856), a novel written by Gustave Flaubert (1821-1880) that became controversial in France for its frank depiction of sexual behavior and adultery-both taboo topics in a France that remained dominated by the Church (Udasmoro, 2015). Leaders of the Church vehemently criticized the novel, which they argued undermined traditional values, and Flaubert was charged and tried for obscenity. Ultimately, Church leaders' opposition expanded to all forms of realism, which they perceived as undermining public morality.

Positioning themselves as moral guardians, Church leaders rejected realism from departing from the divine values upon which French morality was based. Monsignor Félix Dupanloup (1802-1878), the Bishop of Orléans and proponent of French Orthodoxy, decried realism in his Avertissement à la jeunesse et aux père de la famille (A Warning to the Youths and the Fathers of the Family, 1863), 
claiming that the work (as with other realist novels) was an insidious means of negating traditional values. He also made similar claims about other French writers, including Ernest Renan (1823-1892), Louis Ferdinand Alfred Maury (1817-1892), Hippolyte Taine (1823-1893), and Émile Littré (1801-1881), writing:

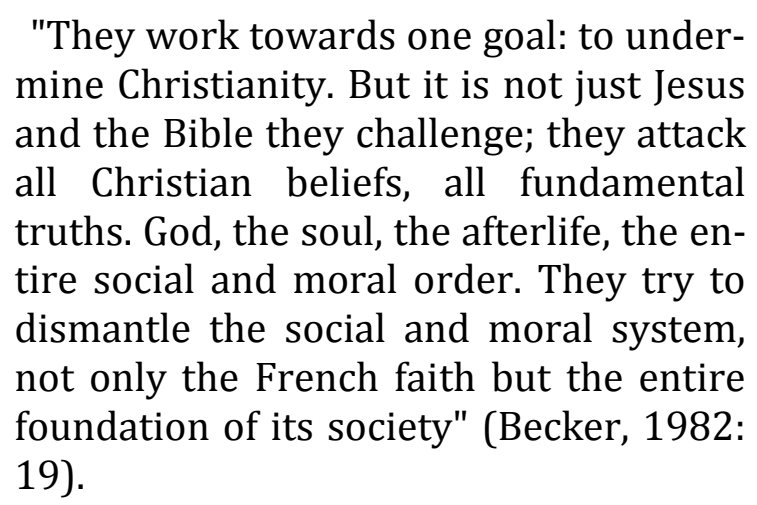

The Church, thus, perceived realism as threatening long-held French beliefs and identities. The Church considered that French long tradition of Christianity would be threatened by the rise of rationalism and also realism. Realists, though still challenging the dominance of the Church, were careful not to draw its wrath.

Flaubert distinguished himself from his contemporaries through his objective and anonymous perspective. He did not make himself manifest in his work, relying on mathematical certainty and objective reality. Any personal morality is presented implicitly, rather than explicitly. Charles Augustin Sainte-Beuve (1804-1869), one of the most prominent literary critics of the time, praised Flaubert for his economical use of language to make sharp observations that reflected the spirit of his time. Flaubert was careful to avoid including himself in his work, emphasizing instead an objectivity that concealed his authorship (Becker, 1982: 144). Thus, Flaubert was more interested to look at the social reality in everyday life longtime hidden in French literary discourse because of the Church's control in the name of morality. However, his perspective in trying to show the reality had to wait several decades to have acceptance from French people and authorities.

Almost a century after Flaubert introduced progressive realism, and in the decade following World War II, two French thinkers rose to prominence: Jean-Paul Sartre (1905-1980)known for such works as L'Etre et le néant (Being and Nothingness, 1943) and L'Existensialisme est un humanism (Existentialism Is a $\mathrm{Hu}-$ manism, 1946)-and Albert Camus (19131960) - known for such works as L'Etranger (The Stranger) (1941) and Le Mythe de Sisyphe (The Myth of Sisyphus) (1942) (Udasmoro, 2012; Udasmoro \& Shahab, 2013).

Sartre $(1943,1946)$ argued that essence must precede existence, with the human selffunctioning both to etre-en-soi (being-in-itself) and etre-pour-soi (being-for-itself). Humans are their own deeds; as such, they must be accountable for all of their actions. Although humans are born free, this freedom comes with responsibility; human beings must make choices and be responsible for said choices. Consequently, philosophy must not be founded in 
transcendality (be it created by God or another force), but in human subjectivity. In this, Sartre expanded upon Descartian thought even as he rejected its transcendental components.

Meanwhile, in his Le mythe de Sysiphe (1942), Albert Camus viewed life as absurd. For his transgressions against the gods, Sysiphe was forced to roll a boulder up a mountain. As the boulder would roll backward every time it reached the peak, this punishment was eternal. Drawing parallels with this myth, Camus argued that human life is useless, pointless, and directionless. Nonetheless, human beings must be responsible for their actions and maintain solidarity with their peers. This world is absurd and does not have meaning. However, the absurdity is not located in the world. It is located in the confrontation between human being and their world:

" Mais ce qui est absurde, c'est la confrontation de cete irrationel et de ce désir éperdu de clarté dont l'appel résonne au plus profond de l'homme. L'absurde dépend autant de l'homme que du monde" (Camus, 1942: 37).

(But what is absurd is the confrontation of this irrational and the wild longing for clarity whose call echoes in the human heart. The absurd depends as much on man as on the world).

Through their philosophies of absurdism and existentialism, Camus and Sartre wrought significant change in French thought
(Udasmoro, 2012). Realism, which traced its roots to the Enlightenment and shaped France between the nineteenth and early twentieth centuries, lost its meaning. Sartre's absurdism could not be separated from the period of war where France was in the situation of uncertainty. If during Flaubert period he questioned the power of the Church, during existentialism, Jean-Paul Sartre and Albert Camus attempted to understand human relation with God. They emphasized that human should be responsible for themselves by avoiding the dependence to God.

Realism was further challenged by Tahar Ben Jelloun (b. 1944), a Moroccan born novelist who rose to prominence through such novels as L'enfant de sable (The Sand Child, 1985) and La nuit sacrée (The Sacred Night, 1985). Ben Jelloun argued that realism was inherently illogical, as it is impossible to capture reality in any medium:

"I sometimes say that I don't do realism because realism is impossible. Those who say that it's possible to photograph or write reality are fooling themselves. Because reality is crazy, it's nuts. To go and capture it, neither photography nor cinema nor drawing-and especially not TV-no one can do that." (Spear \& Litherland, 1993: 43)

Ben Jelloun emphasized the image and the imaginary, rejecting the realist notion of certainty. Ben Jelloun's novels have been classified as magical realism, a literary approach that first emerged in Germany in 1925 but only gained widespread recognition after Gabriel García 
Márquez (1927-2014) received the 1980 Nobel Prize for Literature for his novel Hundred Years of Solitude (1967). Ben Jelloun likewise received critical recognition, becoming the foreign-born author to receive the Prix Goncourt (Pramudita, 2013). Although his receipt of this prize was questioned, the rational law of France stated that he must be accepted. Even though magical realism had long existed in France, and been rejected by the French people, the positivistic paradigm of its society compelled his acceptance. The presence of Tahar Ben Jelloun as part of French literary milieu showed on the one side, the acceptance of non-French (Maghreb) author but on the other side showed also the paradox where Ben Jelloun attempted also to negotiate between the culture he came from with the ideas usually presented in French literature. From this context, the magical realism appeared as part of Ben Jelloun's construction on objectivity and in the same time subjectivity. He blended between the rationality and the irrationality. The irrationality avoided by French literary mindset had to be transformed in accordance with the social context where different cultural groups started to develop in French social structure. Thus, the acceptance of Ben Jelloun's perspective on irrationality had a strong relation with French social changes, especially after the decolonization.

This article is not arguing that the presence of the non-French (Maghreb) author created the rise of irrationality in French literature. However, the diversities of cultures made the possibility of different perspectives and mindsets to be developed as part of the dynamic in French Literature.

The next question is why French literature, being deeply rooted in Descartian positivism and rationalism, has given way to irrationalism. The answer is that rationalism has, since its inception, always incorporated a degree of irrationalism. Rationalism drew from humanism, from totalitarianism (Young, 2005: 38), which must inexorably include opposition. In the case of Ben Jelloun, this resulted in the explicit acceptance of magical realism as part of French literature, decades after its introduction.

\section{CONCLUSION}

Madame Bovary (1856) is a novel without a subject, presenting only a realist attempt to present objective reality in accordance with natural law. Decades later, in works such as $L a$ Nausée (Nausea, 1938) and L'existensialisme est un humanisme (Existentialism Is a Humanism, 1946), presented his philosophy of existentialism-an existentialist humanism. Camus, through L'Etranger (The Stranger, 1941) also challenged the irrationality of natural law through his concept of individual liberty.

This article has traced the development of French literature, from the realist to the irrational, from the Descartian cogita ergo sum to 
Poetika : Jurnal Ilmu Sastra

Vol. 8 No. 2, December 2020
DOI 10.22146/poetika.58651

ISSN 2338-5383 (print) ; 2503-4642 (online) the Sartrian existentialism and Camusian absurdism. Where Sartre and Camus had rejected natural law and its irrationality, Tahar Ben Jelloun-through his novels L'enfant de sable (The Sand Child, 1985) and La nuit sacrée (The Sacred Night, 1987)—urged the French to embrace the irrational. Ultimately, the rationality of realism was a main driver of this acceptance, as it stated that these works (though irrational) had to be recognized as fine examples of French literature that embodied such revolutionary ideas as liberté (liberty), égalité (equality), and fraternité (fraternity). There has thus been a shift in French thought, from rationalism to absurdism to irrationalism. Such a shift is particularly prominent in literature.

This shift of perspective cannot be separated from the change of social transformation in France. The rise of rationalism during the era of enlightment, the World War II, and also the acceptance of the French writers from the Maghreb background created new dimensions in the development of French literature. However, one thing that can be learn from these French dynamics in literature is that the question of liberty has been the prominent aspect in the development of French overall literature.

\section{REFERENCES}

Becker, George J. (1982). Realism in Modern Literature. California: Frederick Ungar Publishing.
Becker, George J. (1982). Realism in Modern Literature. New York: Frederick Ungar Publishing.

Ben Jelloun, Tahar. (1985). L'Enfant de sable. Paris: Èditions du Seuil.

Ben Jelloun, Tahar. (1987). La nuit sacrée. Paris: Èditions du Seuil.

Bryant, Christopher G. A. (1985). Positivism in Social Theory and Research. New York: St Martin's Press.

Camus, Albert. (1941). L'Etranger. France: Gallimard.

Camus, Albert. (1942). Le mythe de sisyphe, Essai sur l'absurde. France: Gallimard.

Flaubert, Gustave. (1856). Madame Bovary. Paris: Revue de Paris.

Foucault, Michel. (1969). L'archéologie du savoir (The Archaeology of Knowledge). Paris: Gallimard.

Hadimaja, Aoh K. (1972). Aliran Klasik, Romantik dan Realisme. Jakarta: Pustaka Jaya.

Hatfield, Gary. (1993). Historical Roots of Cognitive Science: The Rise of a Cognitive Theory of Perception from Antiquity to the Nineteenth Century. Theo C. Meyering. Philosophy of Science, 60(4), 662-666. https://doi.org/10.1086/289768

Hatfield, Gary. (2008). Descartes: A Biography; Cogito, Ergo Sum: The Life of René Descartes. Isis, 99(1), 177-178. https:// doi.org/10.1086/589357

Hatfield, Gary. (2013). Russell's Progress: Spatial Dimensions, the From-Which, and the At-Which. In D. Emundts (Ed.), Self, World, and Art: Metaphysical Topics in Kant and Hegel (pp. 321-44). De Gruyter. Retrieved from https://philarchive.org/rec/HATRPS

Kelly, Jill. (1991). Photographic Reality and French Literary Realism: NineteenthCentury Synchronism and Symbiosis. The French Review, 65(2), 195-205. Retrieved from stable/395589

Lagarde, A., \& Michard, L. (1966). XIXe siècle: Les Grands Auteurs français du programme-Anthologie et Histoire littéraire (Français). Paris: Les editions Bordas.

Masci, David. (2019, February 6). The History of The Evolution Debate in the United States. Retrieved August 9, 2020, from Pew Research Center's Religion \& Public Life Project. https://www.pewforum.org/ 
Poetika : Jurnal Ilmu Sastra

Vol. 8 No. 2, December 2020
DOI 10.22146/poetika.58651

ISSN 2338-5383 (print) ; 2503-4642 (online) essay/darwin-in-america/

Pramudita, Kanya. (2013). Resistensi Kritik dalam L'Homme Rompue Karya Tahar Ben Jelloun. [Master Thesis, Universitas Gadjah Mada, Yogyakarta].

Rehandini, Ajeng. (2015). Transformasi Karakter dalam Novel dan Film Madame Bovary (Character Transformasi in Madame Bovary Novel and Film) (Universitas Gadjah Mada). [BA Thesis, Universitas Gadjah Mada, Yogyakarta]. Retrieved from http://digilib.fib.ugm.ac.id/book/ detail/10674

Sartre, Jean P. (1943). L'Etre et le néant. Paris: Librairie Gallimard.

Sartre, Jean P. (1946). L'existensialisme est un humanisme. Paris: Edition Nagel.

Spear, T., \& Litherland, C. (1993). Politics and Literature: An Interview With Tahar Ben Jelloun. Yale French Studies, (83), 30-43. https://doi.org/10.2307/2930086

Stendhal. (1830). Le Rouge et Le Noir. Paris: Levrasseur.

Stendhal. (1839). La Chartreuse de Parme. Paris: Livre de Poche.

Tang, Shiping. (2017). Toward Generalized Evolutionism: Beyond "Generalized Darwinism" and Its Critics. Journal of Economic Issues, 51(3), 588-612. https:// doi.org/10.1080/00213624.2017.13538 71

Udasmoro, Wening. (2012). Kebebasan dan Ketidakbebasan dalam Cerita Pendek "Tembok" Karya Jean-Paul Sartre Kajian Sosiologi - Hegemonis. Humaniora, 10 (1), 53-59. https://doi.org/10.22146/ jh.609

Udasmoro, Wening. (2015). Paradoksalitas Pemosisian Perempuan dalam Novel Colomba Karya Prosper Mérimée. Jurnal Kawistara, 5(1). https:// doi.org/10.22146/kawistara.6399

Udasmoro, Wening, \& Shahab, A. (2013). Kontestasi Ideologi dalam Sastra Prancis Masa Perang Dunia Kedua. LITERA, 12 (2). ltr.v12i02.1549

Uzgalis, W. L. (1988). The Anti-Essential Locke and Natural Kinds. The Philosophical Quarterly (1950-), 38(152), 330339. https://doi.org/10.2307/2220132

Uzgalis, W. L. (2017). Locke, John. In The
Wiley-Blackwell Encyclopedia of Social Theory (pp. 1-2). American Cancer Society. https:// doi.org/10.1002/9781118430873.est0483

Watt, Ian. (1982). Litérature et Réalité. Paris: Edition de Seuil.

Young, Robert J.C. (2005). White Mythologies: Writing History and the West. London and New York: Routledge. 